\title{
ОЦІНКА ПЕРСПЕКТИВ ВІДТВОРЕННЯ УКРАЇНСЬКОГО НАСЕЛЕННЯ
}

\author{
Т. В. Мукшименко, Б. А. Локай \\ Київський міський медичний коледж \\ ДВНЗ «Тернопільський державний медичний університет \\ імені І. Я. Горбачевського МОЗ України"
}

У роботі представлено порівняльний статистичний аналіз змін моделі народження та режиму старіння населення України та окремих східноєвропейських країн. Розроблено сценарії демографічної поведінки українського населення на середньострокову перспективу. Результати статистичного моделювання характеристик відтворення дають змогу не тільки оцінити характер та масштаби можливих змін, але і скоректувати стратегію державної демографічної політики України.

\section{AN ESTIMATION OF POPULATION REPLACEMENT PROSPECTS IN UKRAINE}

\author{
T. V. Mukshymenko, B. A. Lokay \\ Kyiv City Medical College \\ SHEI «Ternopil State Medical University by I. Ya. Horbachevsky of MPH of Ukraine»
}

The article presents comparative statistical analysis of changes in model of birth and ageing conditions of the population in Ukraine and some Eastern European countries. Mid-term scenarios of demographic behavior of Ukrainian population were developed. The results of statistical modeling of reproductive characteristics allow not only to assess the nature and the extent of possible changes, but also to adjust the strategy of the governmental demographic policy of Ukraine.

Вступ. Укра на, як і більшість європейських кра н, перебуває у стані демографічно зрілості, а впродовж останніх десяти років почала приєднуватись до так званого «другого демографічного переходу». Перший і другий демографічні переходи відрізняються характером причинно-наслідкового зв'язку двох складових природного відтворення. Якщо за першого демографічного переходу регулятором відтворювальних процесів був рівень смертності, то другий перехід супроводжувався, у першу чергу, зміною режиму народжуваності і порядку формування шлюбно-сімейних відносин. Довготривале збереження вкрай низького рівня народжуваності, що не забезпечує простого відтворення, призводить до старіння населення, тобто зростання частки населення з більш високою смертністю. Згідно з концепцією, розробленою Р. Лестегом та Д. Ван де Каа, другий етап демографічного розвитку постіндустріаль-

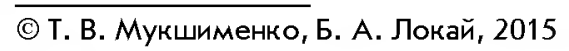

них кра н супроводжується зміною соціально-демографічних норм поведінки населення, переглядом його життєвих пріоритетів у бік індивідуалізаці. Наслідком цього є зміна режиму народжуваності, порядку планування сім' та формування шлюбно-сімейних відносин, зокрема поширення незареєстрованих шлюбів, особливо серед молоді, а отже, і частки позашлюбних народжень. Характерним $€$ підвищення віку шлюбних партнерів і зменшення лагу віку наречених. Відтермінування народження первістків і втілення репродуктивних планів у більш старшому віці призводить до зміни вікового профілю народжуваності, зокрема зміщення модального віку народжень у бік старшого материнського контингенту. Усе це впливає не лише на інтенсивність дітонародження, а і на сталість рівнів народжуваності упродовж певного часу.

Основна частина. Укорінення зазначених процесів формує доволі стійку в часі модель відтворення населення, здебільшого з нульовим або від'ємним природним приростом. Су- 
часний процес еволюці режиму відтворення в різних кра нах має сво особливості, зокрема різний перебіг і тривалість. У більшості кран Східно та Південно Європи спостерігається повторення фаз зміни характеру відтворення населення з певним часовим лагом. Укра на теж демонструє трансформацію моделі народжуваності, шлюбності та режиму дожиття. Як і у більшості кран Східно, Центрально та Південно Європи, в Украні впродовж останніх двадцяти років рівень народжуваності не забезпечує простого відтворення поколінь і за існуючо тенденці рівня смертності не стримує процес депопуляці . Як показує порівняльний динамічний аналіз, кардинальні зміни в Укра ні відбуваються 35 або 9-річним відставанням від сусідніх східноєвропейських кран. Дослідження еволюці демографічних процесів на східноєвропейському просторі впродовж останніх двадцяти років виявляють схожість і водночас особливості $x$ перебігу в кра нах об'єднаних не лише географічною близькістю, а історичною спільністю соціально-політичних систем. До числа таких кран належать: Білорусь, Болгарія, Молдова, Польща, Російська Федерація, Румунія, Словаччина, Угорщина, Укра на та Чеська Республіка. Втім на характер демографічно поведінки населення впливають також його етнічні, культурні, релігійні традиці і спосіб життя. Зокрема, слов'янським народам історично притаманні певні виважені стандарти шлюбносімейно і дітородно поведінки, що регулюються релігійно-етичними канонами. Окрім того, на сучасні процеси дожиття та плідності значною мірою впливає статево-вікова структура населення, яка була деформована Другою світовою війною, зокрема втратою чоловічого населення старших вікових груп та дефіцит поколінь, народжених під час війни і хніх нащадків. Усе це дозволяє обмежити коло порівняних кран, зокрема в подальшому розглядатиметься сім держав: Білорусь, Болгарія, Польща, Російська Федерація, Словаччина, Укра на та Чеська Республіка. Цікаво прослідкувати за основними відтворювальними параметрами поетапно впродовж чотирьох п'ятирічних періодів: 1990-1995, 1995-2000, 2000-2005 і 2005-2010 роки.

Узагальнюючим показником інтенсивності відтворення населення $є$ коефіцієнт природного приросту [1]. Усі кра ни переживали тривале скорочення природного приросту з переходом до нульового (Польща, Словаччина) та різно інтенсивності від'ємного приросту (рис. 1). Очевидним $є$ практично повний збіг траєкторій зменшення природного приросту населення Укра ни та Білорусі, яке упродовж п'ятнадцятирічного періоду спостерігали в групі з надзвичайно низькими рівнями народжуваності і мало схожу статево-вікову структуру, спотворену наслідками Друго світово війни. Втім Укра на вирізняється на загальному фоні масштабами та довготривалістю природних втрат, підсилених загостренням соціально-економічно та політично кризи. В усіх кра нах пострадянського простору, а також у Болгарі та Чеській Республіці природні втрати населення стрімко наростали впродовж п'ятнадцяти років, а період 20002005 рр. був найтяжчим і характеризувався значним перевищенням смертності над народжуваністю, що спричинило падіння усіх кран до так звано "демографічно ями». Це насамперед відбувалося внаслідок зміни режиму народжуваності, зокрема інтенсивного скорочення рівня народжуваності серед умовних поколінь. Дивовижний феномен переходу від критично низького рівня до показника, що наблизився до 1,5 дитини, демонструють Чехія i Болгарія, де активно запроваджувалась політика економічно підтримки сімей. Для реальних поколінь післявоєнних років народження (1955-1959, 1960-1965, 1966-1969 рр.) також притаманна спільність рівнів народжуваності та динаміка. Зокрема, в Польщі та Словаччині вичерпана плідність зазначених когорт становила, відповідно: 2,2; 2,1; 1,94 і 1,98 дитини. Аналогічну близькість рівнів сумарно плідності трьох реальних поколінь демонструють Укра на, Білорусь та Росія (1,9; 1,8; 1,6 дитини).

В останньому періоді населення кран пострадянського простору також переживають демографічний підйом, спричинений одночасним зростанням народжуваності та зменшенням смертності, у тому числі завдяки поповненню старших вікових груп найменш чисельною когортою народжених під час війни. Неабиякий злет здійснила Росія, хоча і й за сприятливого демографічного ресурсу поки що не вдалося вибратись із стану звуженого відтворення. Лише три кра ни «західно частини» Східно Європи (Словаччина, Польща, Чехія) подолали межу від'ємного приросту.

Найвищий рівень навантаження населення працездатного віку старшими особами систематично демонструють Болгарія, Укра на та Чеська Республіка. До того ж у перших двох кра нах і в Польщі найвищі темпи зростання демографічного навантаження. Усе це свідчить про поглиблення процесу старіння та зменшення потенціалу кра н для подальшого відтворення у найближчій перспективі. 3 іншого боку, старіння населення $€$ своєрідною платою за подовження тривалості життя. 


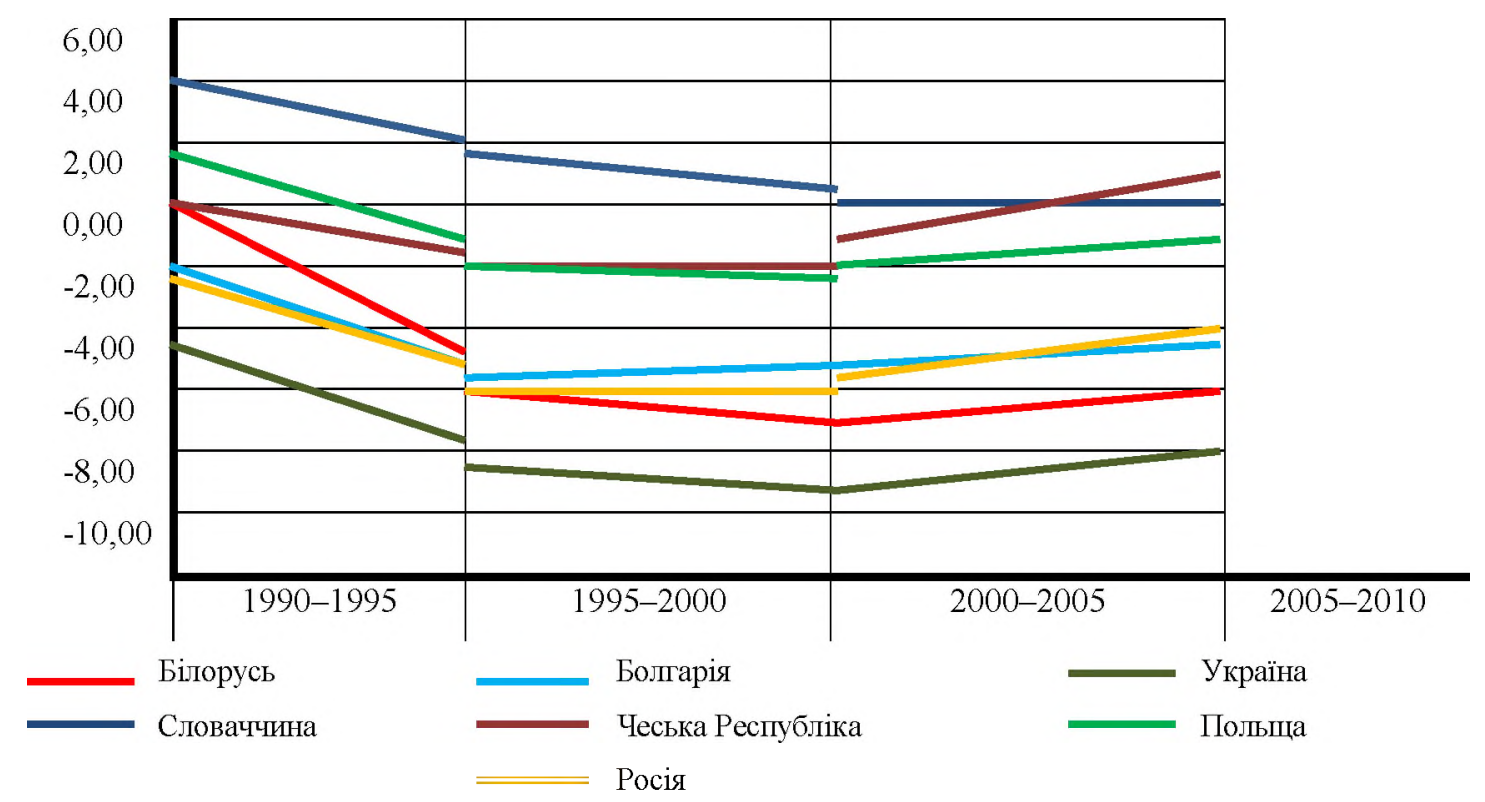

Рис. 1. Динаміка коефіцієнта природного приросту в східноєвропейських країнах 1990-2010 рр.

На тлі загально тенденці зростання середньо очікувано тривалості життя чітко виокремлюються дві групи кран, де показник набував значень до 70 років - пострадянські держави: Білорусь, Росія та Укра на, а також вище 70 років - держави колишнього соціалістичного табору: Болгарія, Польща, Словаччина та Чеська Республіка. Причому остання кра на вирізняється не лише найдовшою тривалістю життя (77 років у середньому за 2000-2005 рр.), а і найвищим темпом зростання $(+6,2 \%)$. У так би мовити змаганні між Словаччиною та Польщею на перші позиці вийшла друга кра на. Болгарія посідає проміжне місце між «заходом» і «сходом». Вочевидь така диференціація пов'язана із різним рівнем соціально-економічного розвитку кран, життєвих стандартів і добробуту населення. Не дарма за значенням індексу людського розвитку в 2012 р. Чеська Республіка посідає 28 місце, Словаччина і Польща, відповідно, 35 і 39, а Болгарія 57 позицію у світовому рейтингу з числа 94 кра н. У другій групі кра н практично в унісон поволі зростала тривалість життя Укра ни та Білорусі, впритул наблизившись до 70-річного віку і тим самим повернувшись до рівня 19901995 рр. Відмінний від усіх кран тренд демонструє Росія із значним скороченням середньо очікувано тривалості життя до 65 років і стрімким його зростанням до майже 68 років у наступному п'ятирічному періоді. Останніх п'ять років рівні дожиття обох статей в Росі та Укра ні зрівнялися завдяки швидкому зростанню дожиття російського населення у працездатному віці і через його зниження в Украні. Варто зазначити, що на динаміку повільного зростання середньо очікувано тривалості життя при народженні укра нського населення впливало скорочення смертності лише у ранньому дитячому віці (05 років) та у старших вікових групах. У той же час «болючим» питанням для Укра ни залишаються неприродні втрати чоловічого населення активного працездатного віку (30-49 років), смертність яких перевищує жіночу смертність у 3-3,4 раза. Причини чоловічо надсмертності в Укра ні здебільшого криються у способі життя чоловіків, характері роботи та у ставленні до власного здоров'я. Тобто поліпшення режиму дожиття населення лежить у площині соціально-економічного становища кра ни, життєвого рівня і способу життя населення. Саме це значною мірою пояснює диференціацію показників демографічно поведінки в кра нах, які формально відносять до єдиного географічного простору східноєвропейських держав.

Узагальнюючу картину позицій згаданих кра н з точки зору природного відтворення населення можна скласти за допомогою кластерного аналізу. Кластеризація здійснювалась за трьома блоками показників:

- узагальнюючі демографічні показники;

- інтенсивність дожиття та смертності;

- дітородна активність жінок.

Для зменшення варіаці показників використовувались $\mathrm{x}$ середньорічні значення по кожному 3 чотирьох п'ятирічних періодів (19901995, 1995-2000, 2000-2005 і 2005-2010 рр.). Упродовж 1990-2010 рр. згадані кра ни утворили два сталих угрупування: пострадянські 
(Білорусь, Російська Федерація, Укра на) і про радянські в минулому, а тепер практично усі за виключенням Болгарі - нові члени Євросоюзу. У другій групі найбільшу близькість демонструють Польща і Словаччина, причому цей тандем кожні п'ять років зберігається незмінним.

Найбільша евклідова відстань характерна для Чесько Республіки і чим далі, тим вона $\epsilon$ дужчою. Відокремленість Чехі пояснюється більш високим рівнем і динамікою соціальноекономічного розвитку та більшу орієнтацію на «західні» стандарти життя 3 огляду на географічне сусідство та етнічні особливості населення. Дещо осторонь від усіх сто ть Болгарія, яка займає проміжну позицію між західними і східними сусідами. Населення Болгарі має режим дожиття майже як у “західних" кра нах, а рівень народжуваності та старіння, як у “східних". В Укра ні впродовж 1990-2005 рр. та в Білорусі маючи майже однакові показники природного відтворення, тривалості життя і смертності немовлят. В останньому п'ятиріччі збільшилась відстань між показниками дожиття населення Білорусі та Укра ни і остання об'єдналась в ок- ремий підкластер з Росією. Це відбулося завдяки тому, що, по-перше, Росія наздогнала Укра ну за показниками тривалості життя. По-друге, в Украні, як і в Росі, дещо зросла сумарна народжуваність в умовних поколіннях і змінився віковий профіль народжуваності у бік старіння матерів. Таким чином, характер відтворення населення обох кра н став більш подібним. Втім зміна порядку дітонародження, зокрема календаря народжень, поширення позашлюбних народжень в Укра ні відбувається з деяким відставанням від Росі. 3 5-річним лагом Укра на відстає від Росі і Білорусі за рівнем і темпами зниження смертності немовлят. Окреслені зміни дозволяють припустити, що впродовж наступних 10 років Укра на може повторити сценарі перебігу демовідтворювальних процесів Росі та Білорусі. Різноваріантні сценарі прогнозу дозволяють оцінити масштаби імовірних змін у чисельності та статево-віковому складі населення Укра ни, ступені його старіння, забезпечення репродуктивним потенціалом на найближчу перспективу (табл. 1).

\section{Таблиця 1. Фактичні та гіпотетичні значення показників відтворення населення України}

\begin{tabular}{|l|c|c|c|}
\hline \multicolumn{1}{|c|}{ Показники } & Фактичні значення & \multicolumn{2}{|c|}{ Гіпотетичні значення у 2020 р. } \\
\cline { 3 - 4 } & у 2011 p. & сценарій 1 & сценарій 2 \\
\hline Середня очікувана тривалість життя чоловіків, роки & 66,0 & 66,6 & 69,0 \\
\hline Середня очікувана тривалість життя жінок, роки & 75,9 & 77,0 & 77,2 \\
\hline Смертність немовлят, \%о & 9,0 & 7,3 & 7,0 \\
\hline Сумарний коефіцієнт народжуваності, дитина & 1,459 & 1,586 & 1,546 \\
\hline Нетто-коефіціснт відтворення & 0,693 & 0,759 & 0,731 \\
\hline Середній вік матері, роки & 27,2 & 27,6 & 27,5 \\
\hline Коефіцієнт природного приросту, \%о & $-3,5$ & $-4,9$ & $-5,1$ \\
\hline
\end{tabular}

Обидва сценарі прогнозують зростання від'ємного природного приросту, хоча укра нський сценарій (сценарій 1) видається більш оптимістичним. Завдяки інтенсивнішому збільшенню сумарного коефіцієнта народжуваності, а відтак і нетто-коефіцієнта відтворення, природні втрати населення наростатимуть повільніше. Якби укра нське населення перейшло на режим дожиття російського і білоруського населення із зменшенням смертності населення в працездатному віці, то зростання середньо очікувано тривалості життя було б помітнішим. Сценарій народжуваності в сусідніх кра нах, із зміщенням піку плідності у старші вікові групи, зменшить інтенсивність відтворення материнського покоління. Очікувані зміни у характері відтворення населення, з урахуванням повільного зростання сальдо міграційного приросту не спасуть Укра ну від подальшо депопуляці. Гіпотетична чисельність укра нського населення у 2020 р. коливатиметься від 43,77 до 43,87 млн осіб (табл. 2).

Порівняно з пропонованим укра нським сценарієм 1 песимістичним $\epsilon$ середній варіант прогнозу $\mathrm{OOH}$, за якого гіпотетичні показники дожиття укра нського населення значно нижчі, ніж реальні у 2011 р. Зовнішні експерти не вбачають стабільних позитивних змін у соціально-економічному становищі Укра ни та істотних зрушень у поведінці населення щодо поширення здорового способу життя, зменшення рівня травматизму та частки зовнішніх неприродних чинників смерті. 
Таблиця 2. Фактичні і гіпотетичні показники чисельності і структури населення України

\begin{tabular}{|l|c|c|c|}
\hline \multirow{2}{*}{ Показники } & Фактичні значення & \multicolumn{2}{|c|}{ Гіпотетичні 3начення у 2020 р. } \\
\cline { 3 - 4 } & у 2011 p. & сценарій 1 & сценарій 2 \\
\hline Чисельність населення, млн осіб & 45,45 & 43,87 & 43,77 \\
\hline Природний приріст (втрати), тис. осіб & -162 & -217 & -224 \\
\hline Чисельність народжених, тис. осіб & 502,6 & 426,0 & 412,5 \\
\hline Частка населення віком 0-14 років, \% & 14,4 & 16,0 & 15,7 \\
\hline Частка населення віком 15-49 років, \% & 50,0 & 46,5 & 46,7 \\
\hline Частка населення віком 65 і старше років, \% & 15,2 & 16,9 & 16,9 \\
\hline
\end{tabular}

Згідно з усіма сценаріями в Укра ні триватиме процес депопуляці через перевищення смертності над народжуваністю. Навіть значне зростання коефіцієнта сумарно народжуваності до малоймовірного рівня 1,97 дитини не застережить укра нське населення від природних втрат та скорочення його чисельності (табл. 3). Очікувані зміни у віковій структурі населення також не сприятимуть природному відтворенню. Адже усі прогностичні оцінки вказують на змен- шення репродуктивного контингенту віком 1549 років, який у середньостроковій перспективі складатиме менше половини населення. У стані виснаженого демографічного ресурсу, тобто нестатку покоління батьків, Укра на перебуватиме принаймні до 2030-2035 років. Чисельність населення Укра ни станом на 1 січня 2014 р. склала 45 млн 426,2 тис. осіб. Про це повідомляє Державна служба статистики Укра ни (Держстат).

Таблиця 3. Гіпотетичні та прогнозні значення чисельності і складу населення України у 2020 році

\begin{tabular}{|c|c|c|c|c|c|c|c|}
\hline \multirow{2}{*}{ Показники } & \multirow{2}{*}{$\begin{array}{c}\text { Гіпотетичні } \\
\text { значення, } \\
\text { (сценарій 1) }\end{array}$} & \multicolumn{3}{|c|}{ Прогноз ІДСД НАН України } & \multicolumn{3}{|c|}{ Прогноз ООН } \\
\hline & & високий & середній & низький & високий & середній & низький \\
\hline $\begin{array}{l}\text { Чисельність населення, } \\
\text { млн осіб }\end{array}$ & 43,87 & 44,85 & 44,31 & 43,19 & 45,82 & 44,83 & 43,84 \\
\hline $\begin{array}{l}\text { Чисельність народжених, } \\
\text { тис. осіб }\end{array}$ & 426,0 & 494,0 & 457,9 & 423,3 & 565,2 & 441,8 & 318,4 \\
\hline $\begin{array}{l}\text { Природний приріст } \\
\text { (втрати), тис. осіб }\end{array}$ & -217 & $-66,4$ & $-176,8$ & $-306,7$ & $-110,6$ & $-232,3$ & $-353,9$ \\
\hline $\begin{array}{l}\text { Частка населення віком } \\
15-49 \text { років, \% }\end{array}$ & 46,5 & 45,9 & 46,3 & 46,9 & 44,0 & 45,0 & 46,0 \\
\hline $\begin{array}{l}\text { Частка населення віком } 65 \\
\text { i старше років, \% }\end{array}$ & 16,9 & 17,8 & 17,4 & 16,8 & 19,4 & 19,8 & 20,3 \\
\hline
\end{tabular}

При цьому станом на 1 грудня 2013 р., кількість населення Укра ни становила 45 млн 439 тис. 822 людини. Таким чином, за місяць чисельність населення кра ни скоротилася приблизно на 13,6 тис. осіб. Природне скорочення населення у 2013 р. склало 158 тис. 712 осіб. Коефіцієнт природного приросту населення склав $-3,5$ на тисячу жителів Укра ни.

При цьому за 2013 р. чисельність населення Укра ни зменшилася на 126,8 тис. осіб - на 1 січня 2013 р. цей показник становив 45 млн 553 тис. Раніше Держстат прогнозував чисельність населення Укра ни на 1 січня 2014 р. на рівні 45 млн 419,8 тис. осіб. За грудень 2013 р. чисельність населення кра ни скоротилася на 7 тис. 188 осіб.

Масштаб нинішньо демографічно депресі неможливо пояснити лише відомими соціально-економічними та медичними чинниками. Проблема полягає в соціально-психологічному й моральному стані суспільства. Населенню ніхто не пояснив замислу економічних і політичних перетворень і що на них чекає в майбутньому.

За даними досліджень, 72 \% громадян зазначають, що не впевнені у власному майбутньому. Лише 12 \% вважають, що найближчого року хнє життя більш-менш налагодиться. Люди не витримують безпросвітного життя. Масови- 
ми стали зневіра, невтішність, озлоблення. Найхарактернішими ознаками сьогодення, за оцінками громадян, є розвал економіки (55\%), хабарництво (55\%), безробіття (49\%), зубожіння населення (47\%).

У повсякденному житті окремо людини та сім' виникають страхи, соціальні фобі . Укра нські громадяни бояться: безробіття (76 \%), зростання цін (75\%), невиплати зарплати (69 \%), зростання злочинності (60\%), голоду (53\%). За таких умов ціла нація втратила сенс буття і вже як наслідок - різке скорочення народжуваності, зростання смертності, масова еміграція.

До 2020 р. посилюватиметься процес старіння укра нського населення, за якого частка осіб віком 65 років і старше коливатиметься в межах 17-18 \%. У такому разі залишається розраховувати насамперед на подовження тривалості життя населення дітородного і економічно активного віку. Ще одним резервом може бути міграційний приріст населення. За кардинального покращення соціально-економічних умов це повернення на батьківщину укра нських мігрантів, у тому числі трудових. За гірших - приплив мігрантів з азійських кран, для яких Укра на $\epsilon$ транзитною державою на шляху до розвинутих європейських кран.

Висновки. Порівняльний аналіз перебігу демографічних процесів в Украні та в сусідніх кра нах Східно Європи показав схожість тенденцій відтворення населення. Найбільш очевидним $\epsilon$ збіг динаміки народжуваності, зокрема коливання Фаз падіння і підвищення.

\section{ЛITEPATУРA}

1. Human Development Report 2013. The rise of the South: Human Progress in a Diverse World [Текст]. One United Plaza, NY : 2013. - 203 p.

2. Захаров С. Место России по уровню рождаемости по ряду стран [Электронный ресурс] / С. Захаров. - Режим доступа : http://demoscope.ru/weekly/ 2012/0495/tema04.php.

3. Lesthaeghe R. «Two Demographic transitions?» [Текст] / R. Lesthaeghe, D. J. van de Kaa / / Population Growth and Decline. Deventer, Van Loghum Slaterus, 1986. - P. 9-24.

4. Молодь та молодіжна політика в Україні: соціально-демографрічні аспекти [Текст] / за ред. Е. М. Лібанової. - К. : Ін-т демогр. та соціальних досліджень ім. М. В. Птухи НАН України, 2010. - 248 с.

5. Население России 2009 [Текст] : семнадцатый ежегодный демографический доклад / отв. ред. А. Г. Виш-
Причому характер тренду сумарного коефіцієнта народжуваності як для умовних, так і для реальних поколінь 3-поміж розглянутих східноєвропейських кран принципово не відрізнявся. Відмінності у рівнях сумарно народжуваності зумовлювались різними пронаталістськими заходами з боку різних держав. 3 певним часовим лагом в усіх кра нах поступово формується нова модель народжуваності зі зміненим календарем народжень у бік пізнього материнського віку, відтермінуванням народження первістків, зростанням частки позашлюбних народжень та частки свідомо бездітних пар.

Сучасний режим народжуваності у поєднанні 3 існуючим характером дожиття населення призводить до поступового процесу депопуляці зазначених кран. Різниця полягає лише в тому, що розвинутим східноєвропейським кра нам вдалось вийти зі стану від'ємного природного приросту, а пострадянські кра ни його не здолали, навіть за умов тимчасово сприятливо статево-віково структури населення. На даний час Укра на має демографічний ресурс не гірший, ніж у сусідніх державах. Найближчих десять років відтворювальний потенціал зменшуватиметься внаслідок довготривало кризи народжуваності, а також погіршення характеру дожиття населення економічно активного та дітородного віку. Окреслені тенденці народжуваності та дожиття укра нського населення мають враховуватись при виконанні державних програм щодо здоров'я наці, проведенні медично реформи.

невский. - М. : Изд. дом. Высшей школы экономики, 2011. - 334 c.

6. Paradysz J. An assessment of population development in Western Poland in the light of the 2nd demographic transition [Текст] / J. Paradysz, K. Paradysz / / Вісник Київського національного університету ім. Тараса Шевченка. Серія Економіка. - № 129. - 2010. - С. 21-23.

7. UN Population Division World Population Prospects: The 2010 Revision, available at: http:// www.unpopulation.org/.

8. Позняк О. В. Методика демографрічного прогнозування / О. В. Позняк, П. Є. Шевчук, В. С. Шишкін // Статистика України. - 2000. - Вип. 4. - С. 66-73.

9. Старостенко Г. Г. Методологія і практика досліджень відтворення населення України (регіональний аспект) : монографрія / Г. Г. Старостенко. - К. : УФЕІ, 1997. - $270 \mathrm{c}$. 